\title{
Preface: Quaternary and Tertiary landscapes and their sediments in Hesse, Germany - a guidebook to selected field trips on geology, geomorphology and geoarchaeology
}

\author{
Markus Fuchs \\ Department of Geography, Justus Liebig University Giessen, Senckenbergstr. 1, 35390 Giessen, Germany
}

Correspondence: Markus Fuchs (markus.fuchs@geogr.uni-giessen.de)

Relevant dates: $\quad$ Published: 20 August 2018

How to cite: $\quad$ Fuchs, M.: Preface: Quaternary and Tertiary landscapes and their sediments in Hesse, Germany - a guidebook to selected field trips on geology, geomorphology and geoarchaeology, DEUQUA Spec. Pub., 1, 1-2, https://doi.org/10.5194/deuquasp-1-1-2018, 2018.

This guidebook compiles the field trips offered for the first Central European Conference on Geomorphology and Quaternary Sciences, to be held in Giessen, Germany, from 23 to 27 September 2018. The conference was organized for the first time as a joint meeting of the German Association on Geomorphology (AKG, Deutscher Arbeitskreis für Geomorphologie) and the German Quaternary Association (DEUQUA, Deutsche Quartärvereinigung), following the motto "Geomorphology and quaternary sciences: connecting disciplines".

Giessen and its wider surroundings are located in Hesse and offer a great diversity of landscapes. The lithology comprises rocks from the Palaeozoic to the Quaternary, including the Miocene Vogelsberg massif as the largest volcanic complex in central Europe. The rivers Lahn, Main and Rhine dominate the fluvial system of Hesse, and their Quaternary history is visible in a large variety of sediments and landforms. Soils of the region represent an alternating climate history of the region, reaching back to the Tertiary, and thick loess deposits in the Wetterau region allowed the development of fertile soils, used by farmers in the Neolithic.
The aforementioned geo-tidbits demonstrate what is of fered by one pre-conference and three post-conference day field trips, which provide a geological, geomorphological and geoarchaeological overview of the area, with a focus on the Quaternary. I wish to thank all authors for their contributions to this guidebook. Stefanie Menges is thanked for her editing work and Lisette Diehl for providing some of the figures. Finally, I would like to express my gratitude to the German Research Foundation (DFG) and the Hessian Agency for Nature Conservation, Environment and Geology (HLNUG), who provided financial support for this publication. 


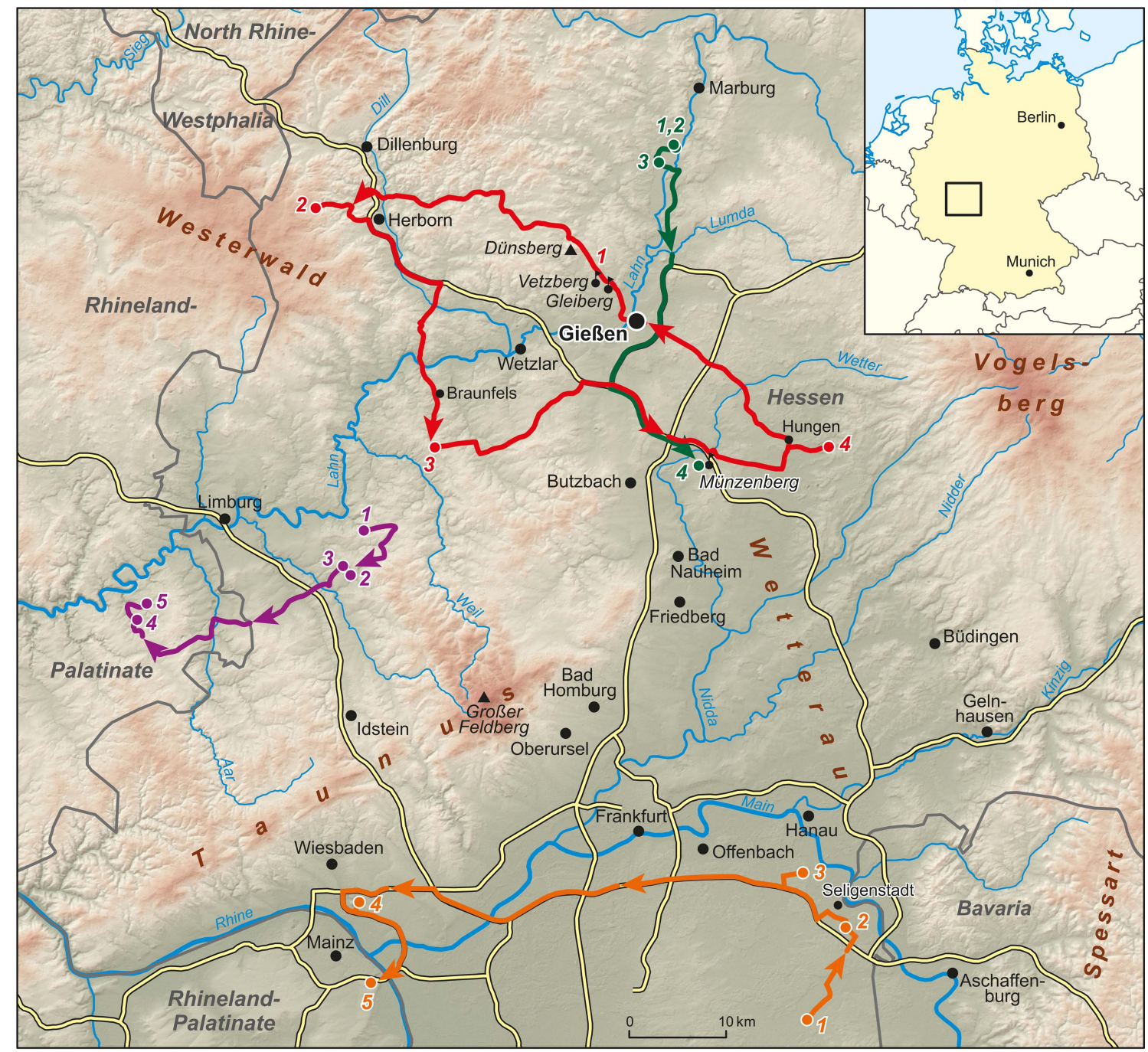

$-\rightarrow$ Field Trip A: geology and geomorphology of Giessen and its surrounding areas (23.09.2018)

$-\rightarrow$ Field Trip B: Quaternary environments of Giessen and its surrounding areas (27.09.2018)

$\longrightarrow$ Field Trip C: fluvial and aeolian deposits of Rhine-Main area (27.09.2018)

$\rightarrow$ Field Trip D: characteristics and development of the Mesozoic-Tertiary weathering mantle and

Pleistocene periglacial slope deposits in the Hintertaunus mountainous region (27.09.2018)

Figure 1. Field trips and their routes offered for the Central European Conference on Geomorphology and Quaternary Sciences, Giessen, Germany. 